\title{
POPULATION AGING, LABOR DEMAND, AND THE STRUCTURE OF WAGES
}

\author{
Margarita Sapozhnikov and Robert K. Triest*
}

\author{
CRR WP 2007-14 \\ Released: October 2007 \\ Draft Submitted: August 2007 \\ Center for Retirement Research at Boston College \\ Hovey House \\ 140 Commonwealth Avenue \\ Chestnut Hill, MA 02467 \\ Tel: 617-552-1762 Fax: 617-552-0191 \\ http://www.bc.edu/crr
}

* Margarita Sapozhnikov is a senior associate at CRA International. Robert K. Triest is a visiting scholar at the CRR and a Senior Economist and Policy Advisor at the Federal Reserve Bank of Boston. The research reported herein received support from The Atlantic Philanthropies and from the U.S. Social Security Administration (SSA), funded as part of the Retirement Research Consortium (RRC). The opinions and conclusions expressed are solely those of the authors and should not be construed as representing the opinions or policy of The Atlantic Philanthropies, SSA, any agency of the federal government, or the Center for Retirement Research at Boston College. The authors thank Jamie Lee and Brendan Mackoff for very helpful research assistance, their Center colleagues for beneficial discussions, and Melinda Pitts, Ron Lee, and Joe Quinn for helpful comments.

(C) 2007, by Margarita Sapozhnikov and Robert K. Triest. All rights reserved. Short sections of text, not to exceed two paragraphs, may be quoted without explicit permission provided that full credit, including (C) notice, is given to the source. 


\title{
About the Center for Retirement Research
}

The Center for Retirement Research at Boston College, part of a consortium that includes parallel centers at the University of Michigan and the National Bureau of Economic Research, was established in 1998 through a grant from the Social Security Administration. The Center's mission is to produce first-class research and forge a strong link between the academic community and decision makers in the public and private sectors around an issue of critical importance to the nation's future. To achieve this mission, the Center sponsors a wide variety of research projects, transmits new findings to a broad audience, trains new scholars, and broadens access to valuable data sources.

\author{
Center for Retirement Research at Boston College \\ Hovey House \\ 140 Commonwealth Avenue \\ Chestnut Hill, MA 02467 \\ phone: 617-552-1762 fax: 617-552-0191 \\ e-mail: crr@bc.edu \\ www.bc.edu/crr
}

\author{
Affiliated Institutions: \\ American Enterprise Institute \\ The Brookings Institution \\ Center for Strategic and International Studies \\ Massachusetts Institute of Technology \\ Syracuse University \\ Urban Institute
}




\begin{abstract}
One consequence of demographic change is substantial shifts in the age distribution of the working age population. As the baby boom generation ages, the usual historical pattern of there being a high ratio of younger workers relative to older workers is increasingly being replaced by a pattern of there being roughly equal percentages of workers of different ages. One might expect that the increasing relative supply of older workers would lower the wage premium paid for older, more experienced workers.

This paper provides strong empirical support for this hypothesis. Econometric estimates imply that the size of one's birth cohort affects wages throughout one's working life, with members of relatively large cohorts (at all stages of their careers) earning a significantly lower wage than members of smaller cohorts. The cohort size effect is of approximately the same magnitude for men and for women. Our results suggest that cohort size effects are quantitatively important and should be incorporated into public policy analyses.
\end{abstract}




\section{Introduction}

Along with virtually all other developed countries, the United States is on the cusp of a radical transformation of its labor markets due to a profound demographic shift. As many have documented, the growth rate of the American working age population has already dropped substantially, and as the baby boomers start to approach normal retirement ages, the elderly dependency ratio (the ratio of those over 65 to the population aged 15 to 65) will increase dramatically. As a consequence, labor supply may grow at a slower rate than labor demand, putting upward pressure on wages and creating tight labor market conditions. Often overlooked, however, is the fact that the age distribution of the labor force will also be changing dramatically. According to Census Bureau projections (2000), the traditional working age (16-64) population of the United States will increase by just 13 percent between 2001 and 2025, but the population aged 60 to 64 will increase by 90 percent. So while there may be a shortage of workers overall, there will be a relative glut of older workers.

The effect these changes may have on the labor market opportunities of older workers is not immediately obvious. Although labor demand conditions are likely to be favorable for workers in general, the large size of the baby boom cohort compared to younger cohorts may place the baby boomers at a relative disadvantage. The same crowding effect that depressed the boomers' wages when they were young (Welch (1979) and others) may continue to haunt them as they enter their 60s. Although there may be upward pressure on wages in general, the relative glut of older workers may depress their wages relative to those of their younger colleagues.

What happens to the wages of older workers, and the structure of wages more generally, as the population ages has potentially important implications for public policy. Many analysts are convinced that longer working lives must be a key component of any solution to providing for the consumption needs of the old as the traditionally defined dependency ratio increases. The efficacy of 
this solution depends, in part, on the wage rates that older workers command in labor markets. If the wages of older workers fall as their ranks become crowded with the baby boomers, then continued work may seem like a less desirable option to those contemplating retirement, and the earnings of those who do continue working will not go as far in financing their consumption.

How the wage structure changes as the baby boomers age also has potential implications for forecasting future payroll tax revenue and Social Security benefits. To the extent that the boomers' wages have been depressed due to cohort size effects, then their exit from the labor market may affect aggregate earnings growth. More generally, the earnings trajectories of those currently in the middle of their careers, as well as those younger workers just starting out, will likely be affected by changes in the age distribution of the population. And changes in earnings trajectories will, of course, result in changes in payroll tax payments and eventual Social Security benefits.

This paper empirically investigates the effects of changes in the age distribution of the working age population on the structure of wages. In particular, we examine the hypothesis that cohort crowding not only affects the wages of large birth cohorts as they enter the labor market but continues to exert downward pressure on the wages of large cohorts as they approach retirement age. We find strong support for this hypothesis. The size of one's birth cohort affects an individual's wages throughout his or her working life, with members of relatively large cohorts at all stages of their careers earning a significantly lower wage than members of smaller cohorts. Our results suggest that cohort size effects are quantitatively important, and thus should be incorporated into public policy analyses.

\section{Previous Research}

There is a sizable research literature examining how changes in the age distribution of the labor force affects the structure of wages. The unifying idea 
underlying this literature is that workers with different amounts of labor market experience are imperfect substitutes in production. Workers acquire human capital through on-the-job training and through learning-by-doing. More experienced workers will generally perform somewhat different tasks than do younger workers, and compared to younger workers will tend to play different roles within a firm's organization. As the supply of labor with a given level of experience increases, the wages of workers in that group will tend to decrease relative to those with different experience levels. The smaller the degree of substitutability between workers with different experience levels, the greater the change in relative wages that will result from a given change in relative supplies. Variance over time in the relative supplies of workers at given levels of experience is essential for estimating the degree of substitution; therefore, most of the studies on this topic are based on examining how relative wages of men with differing levels of labor market experience changed as the baby boom generation entered the labor market. Building on this work, our study uses more recent data than that available to previous researchers, and also analyzes changes in the wages of women as well as those of men. By utilizing wage data extending through 2003, we observe the effects of the oldest baby boomer birth cohort moving through the bulk of their careers, up to age 57. The added variance in relative cohort sizes associated with this recent data is very useful in empirically identifying the effects of changes in the age distribution, and allows us to find direct evidence of the impact cohort crowding has upon the baby boomers' wages as they approach retirement.

In a remarkably prescient analysis written well before the first baby boomers started entering the labor force, Easterlin (1961) notes that the labor market fortunes of workers are inversely related to the relative size of their birth cohort. Easterlin anticipated that as the baby boomer generation entered the labor market, they would face less favorable conditions than the 
cohort that preceded them. ${ }^{1}$

An early, and very influential, econometric examination of the baby boom's effect on relative wages is Welch's (1979) famous study "The Baby Boom's Financial Bust." Using data from the March income and demographic supplements to the Current Population Survey (CPS) from 1968 to 1976, he finds that the wages of young white men were reduced relative to those of older men as the baby boomers started entering the labor market. Noting that the range of potential substitution possibilities is too large to be investigated without some structure, Welch imposes the restriction that substitution between workers with different degrees of educational attainment is independent of their experience levels. Welch estimates the effect of own cohort size on wages, allowing for an interaction between cohort size and labor market experience. The resulting econometric estimates suggest that the relative wage reductions associated with being a member of a large cohort are concentrated in the early years of workers' careers. A concurrent study by Freeman (1979) reaches a similar conclusion-the relative wages of young workers were depressed due to cohort crowding effects. Freeman finds that the effect of the baby boom generation's entry into the labor market on the premium paid to older workers was especially large for college-educated men.

Berger (1985) generally follows Welch's (1979) methodology, but uses additional years of data and a somewhat less restrictive econometric specification. Like Welch, Berger finds that entry-level wages are reduced by cohort size, but unlike Welch, his estimates indicate that the cohort size effect grows with labor market experience. Using a factor analytic technique to decompose the composition of the labor force into a small number of factors, Murphy, Plant, and Welch (1988) find a pattern similar to that found by Welch (1979) - that the depression of wages associated with being in a large cohort is concentrated early in one's career.

\footnotetext{
${ }^{1}$ Easterlin's main focus was on how economic conditions affect fertility, and he correctly predicted that the relatively unfavorable conditions created by the entry of the baby boomers into the labor market would depress fertility rates.
} 
Katz and Murphy (1992) examine the role of cohort size in explaining changes in experience differentials as part of a larger framework exploring how shifts in both labor demand and labor supply affect the structure of wages, and conclude that although the increasing wage differentials associated with labor market experience in the 1970s and 1980s is consistent with the trend of an increasing share of young workers in the labor force, the exact timing of the changes do not match up well. Murphy and Welch (1992) also find that supply shifts alone cannot fully explain changes in the experience differential.

\section{Empirical Patterns}

Following most previous research on this topic, we use data from the annual income and demographic supplement to the March Current Population Survey (CPS). Unlike previous researchers, who observed data for a more limited span of time, we use data for the years 1964-2004. The March supplement survey collects income information for the preceding year, so our wage data spans 1963 through 2003.

\subsection{Changes in the Age Distribution}

Figure 1 shows that striking changes have occurred in the age distribution of the working age population (here defined as ages 18 through 65) over the past 40 years. Each panel of the figure shows the frequency distribution of the working age population for a given year. A growing population is associated with a downward sloping line, while a stable population produces a horizontal line (with each annual birth cohort making up roughly 2.1 percent of the working age population). Barely discernible in 1964, the emergence of the younger baby boomers into their working years is very apparent in the graph for 1974, where young adults greatly outnumber middle-aged and older workers. In 1984, when the youngest baby boomers turned 20, one can see the start of a hump-shaped distribution forming as the post-boom "baby 
bust" generation started to enter their working years. The hump moves to the right between 1984 and 1994, producing an unusual situation in which middle-aged workers outnumber those in both older and younger cohorts.

The 2004 age distribution looks somewhat similar to the 1964 distribution. However, unlike 1964, when the first baby boomers were about to enter the labor force, the working age population distribution will increasingly approximate a uniform distribution over the next few years. The 2014 panel, which is based on U.S. Census Bureau projections, shows a working population that is fairly evenly distributed over all age ranges, with only a modest downward tilt associated with people in their 50s and 60s. The days of there being a large ratio of older to younger workers seem to be over for good.

\subsection{Age and Labor Market Experience}

In order to understand the implications of the changing age distribution for the structure of wages, we need to analyze how the relative supplies of workers with differing levels of educational attainment and labor market experience have changed. Our analysis categorizes individuals into five educational attainment categories: those who did not complete high school, high school graduates, some college (one to three years completed), four year college graduates, and those with post-college graduate education. We aggregate the CPS data into groups defined by this categorization of educational attainment and years of labor market experience.

Researchers using the CPS have typically used age minus years of schooling as a measure of potential labor market experience. However, particularly for women, actual labor market experience is likely to be significantly less than potential labor market experience, with the difference between the two measures strongly dependent on birth cohort. Unfortunately, the CPS does not include information on actual work experience and so we need to impute this information. In constructing the experience variable we follow a non- 
parametric cohort "splicing" approach similar to that used by Herd (2005) in a study of how a minimum Social Security benefit would affect benefit adequacy for women. We interpolate population microdata from the decennial census to form synthetic labor experience histories categorized by gender and educational attainment for birth cohorts from 1900, and then impute the resulting measure of labor market experience to our CPS-based observations. ${ }^{2}$

The importance of using actual rather than potential labor market experience is illustrated by Figures 2 and 3. Over time there has been a sharp increase in the average years of labor market experience for women at any given age and for all levels of educational attainment. The greatest increases, of course, have been for older women, reflecting the cumulative effect of increases in labor force participation at all ages. For all birth cohorts, average labor market experience at any given age increases with educational attainment. Over time, the smallest increases in labor market experience have been at the extremes of the distribution of educational attainment. Women who fail to complete high school accumulate relatively little labor market experience, and women who extend their education beyond college on average accumulate a great deal of experience, but in both cases there have been only relatively minor changes over time. In contrast, for men, the relationship between age and average labor market experience shows little change over time. The main qualification to this statement is that for less-educated men there has been some reduction in the accumulation of labor market experience.

\subsection{Changes in the Distribution of Labor Market Ex- perience}

Following Welch (1979), researchers have generally assumed that substitution possibilities between workers with different experience levels are greater within educational attainment groups than between groups. Pursuing this

\footnotetext{
${ }^{2}$ Details are provided in the Appendix.
} 
assumption, changes in the distribution of labor market experience within the same educational attainment groups are especially relevant for analyzing which changes in the relative labor supplies are most likely to affect relative wages. Figures 4 and 5 are similar to Figures 2 and 3, but show the frequency distribution of labor market experience separately for men and women at two different levels of educational attainment, high school graduate and college graduate. The patterns in Figures 4 and 5 differ from that in Figure 1 primarily because of changes in the average levels of educational attainment over time. ${ }^{3}$ As a result, the impact of the baby boom on the age distribution will differ across educational groups. The entry of the baby boom generation into the labor force had a larger initial impact on the distribution of college-educated workers than it did on high school graduates-the oldest baby boomers were not only much larger in overall numbers than were earlier birth cohorts, but were also much more likely to attend and complete college. The relative cohort size of the oldest baby boom college graduates then decreased over time as the pre-baby boom cohorts were replaced by the younger, even more highly educated, baby boomers. In recent years, the experience distributions of the high school graduates and college graduates have converged, and in the future will increasingly resemble a uniform distribution.

\subsection{Changes in the Experience Premium}

It is evident that cohort size has a large impact on the wage rates of older workers relative to younger workers, as shown in top panel of Figure 6, which charts from 1963 to 2003 the median wage rates of full-time, full year male workers with 22 to 25 years of labor market experience relative to the median wage rates of those with two to five years of experience. ${ }^{4}$ The experience

\footnotetext{
${ }^{3}$ For women, increases in labor force participation over time also play an important role.

${ }^{4}$ We define full-time, full-year workers as those who report working at least 45 weeks in the previous year, and report that they normally work at least 35 hours per week. We
} 
premium is shown only for men in this panel because average experience for women is consistently less than 22 years for all education-birth year groups. Our wage measure is based on individual average hourly earnings, which is annual wage and salary income divided by total hours worked. Total hours worked per year is computed by taking the product of weeks worked the previous year and the usual hours worked per week . The median of individual hourly wages within education-experience groups for each year is used as the group wage measure. ${ }^{5}$ For college graduates, especially, there is a very clear pattern of the experience premium first rising, and then falling with the aging of the baby boomers.

The bottom panel of Figure 6 shows changes in the the premium paid for workers with ten to thirteen years of labor market experience relative to those with two to five years of experience. By focusing on the return to this more limited quantity of labor market experience, we are able to display the premium for both male and female workers in this panel. ${ }^{6}$ However, the difference in the relative supplies of the two experience ranges shown in the lower panel is generally much smaller than those shown in the top panel, and as a result it is difficult to discern the effect of changing relative supplies on the experience premium in the lower panel. A comparison of the upper and lower panels suggests that the exaggeration of the cross-sectional experience premium caused by the entry of the baby boomers was much more pronounced at relatively senior experience levels.

use the CPI-W series to express nominal wage rates in 2004 dollars. As described in the appendix, experience is imputed for each gender-education-age-birth year group.

${ }^{5}$ The median, rather than the mean, of individual wages is primarily used to lessen the impact of outliers.

${ }^{6}$ We are not able to display the experience premium for the "less than high school" women due to the insufficient average work experience of this group. 


\section{Econometric Specification}

The patterns shown in Figures 4, 5, and 6 provide strong evidence that the distribution of labor market experience within educational groups is one determinant of the wage differential between more experienced workers and less experienced workers. This section presents an econometric specification which allows us to more formally estimate this relationship.

Following previous researchers, we specify an aggregate production function treating workers with differing degrees of educational attainment as imperfect substitutes. ${ }^{7}$ Within each educational group, workers with differing levels of labor market experience are imperfect substitutes. Our formal specification is:

$$
Y_{t}=\left(\sum_{j} \theta_{j} E_{j t}^{\rho}\right)^{1 / \rho}
$$

where $Y_{t}$ is aggregate output in year $t, E_{j t}$ is the number of workers with educational attainment $j$ used in production in year $t, \rho=1-\frac{1}{\sigma_{E}}$ and $\sigma_{E}$ is the elasticity of substitution between workers with differing educational attainments. Each $E_{j}$ quantity is in turn a C.E.S. aggregator over workers with differing degrees of labor market experience:

$$
E_{j}=\left(\sum_{k} \alpha_{k} E_{j k}^{\eta}\right)^{1 / \eta}
$$

where $E_{j k}$ is the number of workers with educational attainment $j$ and with $k$ years of labor market experience (the time subscript, $t$, is dropped here), $\eta=$ $1-\frac{1}{\sigma_{A}}$ and $\sigma_{A}$ is the elasticity of substitution between workers with differing years of labor market experience. The wage of a worker in educational group $g$ who has $h$ years of labor market experience is then:

\footnotetext{
${ }^{7}$ Our specific specification most closely follows that of Card and Lemieux (2001).
} 


$$
w_{g h}=\frac{\partial Y}{\partial E_{g h}}=\theta_{g} \alpha_{h}\left(\frac{E_{g h}}{E_{g}}\right)^{\eta-1} E_{g}^{\rho-1}\left(\sum_{j} \theta_{j} E^{\rho_{j}}\right)^{\left(\frac{\rho-1}{\rho}\right)} .
$$

Taking logarithms and rearranging yields an equation for the log wage of workers in educational group $g$ with $h$ years of experience that is linear in the log of the supply of labor with $h$ years of experience relative to the total supply of labor with educational attainment $g$ :

$\ln \left(w_{g h}\right)=\ln \left(\theta_{g}\right)+\ln \left(\alpha_{h}\right)+(\eta-1) \ln \left(\frac{E_{g h}}{E_{g}}\right)+(\rho-1) \ln E_{g}+\left(\frac{\rho-1}{\rho}\right) \ln \left(\sum_{j} \theta_{j} E_{j}^{\rho}\right)$.

We use this equation as the basis for our estimated labor demand relationship. The data we use for estimation is organized such that each observation is specific to a given gender-educational attainment-birth cohort combination. We specify that $\alpha_{h}$, the main experience productivity effect, follows a piecewise linear spline in years of labor market experience, with nodes at three, six, nine, and fifteen years of experience. ${ }^{8}$ This approach is more flexible than the quadratic specification often adopted.

We interact the relative cohort size term, $\ln \left(\frac{E_{g h}}{E_{g}}\right)$, with a set of indicator variables corresponding to the five segments of the experience spline in order to investigate whether the relative cohort size effect changes as cohort members gain experience, a point of contention in the earlier research literature on the effect of the baby boom generation's entry into the labor market. One difficulty in estimating the C.E.S. specification is that although the inputs in the model are defined in terms of years of labor market experience, our observations are defined by year of birth. As a consequence, the inputs in the empirical implementation of the model are delineated by potential rather than actual years of labor market experience, although the terms in the $\alpha_{h}$

\footnotetext{
${ }^{8} \mathrm{An}$ earlier version of this paper that used data only for men included nodes at 20 and 30 years of experience, but the distribution of female labor force experience necessitated that our highest node be at 15 years.
} 
spline are measured as mean years of actual labor market experience.

Goldin (1992) emphasizes that cohort-specific effects have played an important role in women' expectations and attitudes toward their careers. The major social changes that occurred over much of the past century have resulted in qualitative changes in socialization and the labor market opportunities young women expect to be open to them. And for both men and women, over time there are improvements in the human capital acquired prior to beginning one's career. To control for these effects, we allow for $\ln \left(\theta_{g}\right)$ to vary linearly with year of birth. Because these birth cohort effects are allowed to vary by educational attainment, they also capture changes over time in the relative demand for workers by educational attainment.

We also allow for a time-trend spline, with kink points at five-year intervals, to allow for technical change (changes in the $\theta_{g}$ terms) and for changes over time in aggregate labor supplies $\left((\rho-1) \ln E_{g}+\left(\frac{\rho-1}{\rho}\right) \ln \left(\sum_{j} \theta_{j} E_{j}^{\rho}\right)\right)$. Finally we assume that $\ln \left(\theta_{g}\right)$ incorporates a linear stochastic term. Our reported standard errors and test statistics are robust to the possibility that this term is correlated across observations in a given year to allow for macroeconomic influences on wages, and are also robust to the presence of heteroskedasticity.

\section{Regression Results}

The dependent variable for all of the regressions is the natural log of the median real wage of full-time, full-year workers within cells defined by single years of potential labor market experience, the five educational attainment groups defined above, and single calendar years. The same March CPS data from 1964 through 2004 that was used in the figures is also used here.

Falaris and Peters (1992) and Connelly and Gottschalk (1995) provide evidence that educational investment decisions are affected by demographicallyinduced changes in relative wages, and so it is likely incorrect to treat relative 
cohort size within educational attainment groups as exogenous. In addition, sampling error may be a significant factor in measured changes in relative cohort size over time. To address these problems, we use relative cohort size, defined over all educational groups with the same birth year, as an instrument for relative cohort size defined within educational groups. Overall relative cohort size is very likely to be exogenous in this context, and has smaller sampling variation due to the larger number of observations used in its estimation.

Table 1 presents instrumental variables regression results for the combined sample of men and women. An indicator variable for "female" is included in the specification, and the birth year effect is also allowed to vary by gender. The subsample used for estimation is limited to workers between the ages of 22 and 62 in order to reduce the influence of selection out of the labor force due to schooling or retirement. The measure of relative cohort size used in these regressions is gender specific: it is the ratio of full-time workersin with a given gender, level of educational attainment, and birth year to all full-time workers with the same gender and level of educational attainment. ${ }^{9}$

The relative cohort size coefficients can be interpreted as $\eta-1$ in the context of the C.E.S. specification, or more simply as the elasticity of wages with respect to the relative size of one's own cohort. The estimated elasticities are uniformly negative, which confirms that belonging to a relatively large cohort is associated with depressed wages. These elasticities are also sizable in magnitude, generally hovering around -.1 for high school graduates, and a little over -.05 for college graduates. There is a tendency for the coefficients to decrease in magnitude as educational attainment increases, suggesting the substitutability between workers of differing experience levels increases with educational attainment. This result is somewhat surprising, because one might expect more educated workers to face more sharply delineated career

\footnotetext{
${ }^{9}$ To smooth over sampling variation, cohort size is calculated as a 5 year centered moving average, with weights equal to $1 / 9,2 / 9,1 / 3,2 / 9$, and $1 / 9$.
} 
ladders. For all of the educational groups, the relative cohort size effect varies relatively little with years of labor market experience, implying that relative cohort size is roughly as important to the wages earned late in one's career as it is earlier on in one's work life.

The labor market experience spline coefficients generally imply that although real wages increase rapidly with labor market experience, there is a sharp drop in the growth rate of earnings as this experience increases. Real wage rates tend to level off after 15 years of experience. ${ }^{10}$

In interpreting the relative cohort size coefficients, it is important to remember that these are capturing the effects of cohort size on monetary compensation, and omit the effect on fringe benefits. A massive switch from defined-benefit pensions, in which workers' pension accruals are typically concentrated in the years when they are approaching retirement, to definedcontribution pensions started in the 1980s (Munnell and Sundén (2004)). As a result, inclusion of the value of employer-paid pension accruals in our measure of compensation would likely accentuate the estimated effect of relative cohort size on total compensation.

Tables 2 and 3 are similar to Table 1, but display results for the regression model estimated separately for men and women. For women who did not complete high school the highest experience group (15 years or more) was eliminated, as there were no observations in this experience range.

Surprisingly, the relative cohort size effects for women are very similar to those for men shown in Table 1, with the elasticities of roughly the same order of magnitude for both men and women. Men's and women's wages are depressed by cohort crowding effects by approximately the same magnitude throughout their careers.

\footnotetext{
${ }^{10} \mathrm{We}$ do not include knots in the spline at points beyond 15 years because the experience is measured as within-group averages, and generally does not extend much beyond 15 years for women.
} 


\subsection{Changes in Relative Cohort Size Over Time}

It is not immediately obvious from the regression results how changes in the distribution of labor market experience affect the life-cycle wage profile of a given birth-year cohort-because the relative size of a given birth cohort changes over time. This fact is illustrated in Figure 7, which shows relative cohort size over time for four birth cohorts: those born in 1940, 1950, 1960, and 1970.

Looking first at the data for college graduates shown in the bottom panels of the figure, one sees that the baby boomers born in 1950 comprised an exceptionally large fraction of the college-educated labor force when they first entered the labor market, but their relative size decreased over time as even larger cohorts from the middle years of the baby boom subsequently entered their working years. Those born in 1960, relatively late in the baby boom, were a smaller fraction of the labor force when they first entered the labor market than the early baby boomers were at the same stage of their careers. As the entire baby boom generation matured and increasingly made up the bulk of the college-educated work force, the relative size of any given baby boom birth-year cohort shrank. This decrease is reflected in the gradual convergence of the lines for the 1950 and 1960 birth cohorts in Figure 7. Note that the lines for these two baby boom cohort years are always well above those for both the pre-baby boom 1940 birth cohort, and the post-boom 1970 cohort.

The patterns are somewhat different for high school graduates. Because of changes in the distribution of educational attainment over time, the 1960 birth cohort was a larger fraction of the high school-educated labor force at all levels of labor market experience than was the 1950 birth cohort. Unlike the case of college-educated men, where the early baby boomers had exceptionally large relative cohort sizes, the later baby boom birth cohorts were a larger fraction of the high school-educated labor force than were the early baby boom birth cohorts at all levels of labor market experience. 
The cohort size effects have interesting implications for how one interprets the relationship between wages and labor market experience. The regression coefficients for the labor market experience spline reflect what the wageexperience profile would be for a birth cohort that has a constant relative size (within education groups). In a growing population, a given cohort's relative size will shrink with age. If the relative cohort size coefficients were negative and constant over experience levels, this would result in any given cohort's wage-experience profile being steeper than the experience spline coefficients indicate. A decrease in the population growth rate would eventually flatten the wage-experience profile, producing cohort wage-experience profiles closer to that implied by the experience spline coefficients. At a given point in time, the cross-sectional wage-experience profile will reflect the pattern of relative cohort sizes experienced by the birth cohorts in the labor force at that time, and will generally differ both from any given cohort's wage-experience profile and from the constant relative cohort size wage-experience profile implied by the experience spline coefficients.

\section{Conclusion}

The age distribution of the American working age population is becoming flatter, and will soon approach a uniform distribution. The historical pattern of there being a relatively large number of inexperienced young people working alongside a relatively small number of more experienced older workers is being replaced by a labor force where the numbers of older and younger workers are roughly equal. The change in the relative supplies of older and younger workers can be expected to change the experience premium that older workers can command in the labor market.

Large birth cohorts depress their own wages relative to those of other cohorts in the labor force at the same time, with reductions roughly equal in magnitude for men and women. The increase in the cross-sectional labor 
market experience premium induced by the baby boom generation's entry into the labor market is now being offset by a decrease in the cross-sectional experience premium as the baby boomers progress through middle age and approach retirement.

These results imply that older workers will face increasingly unfavorable relative labor market conditions as their ranks become crowded by the baby boom generation in the near future. Although the slowing of labor force growth may create tight labor markets, the pecuniary benefits of labor market tightness will disproportionately accrue to younger, less experienced workers. Loss of defined benefit pensions and increases in Social Security's normal retirement age may result in baby boomers retiring at older ages than did the birth cohorts that immediately preceded them, but the boomers will suffer from the same cohort crowding effects on wages, as they consider retirement that they did earlier in their careers.

\section{References}

Berger, Mark C. 1985. "The Effect of Cohort Size on Earnings Growth: A Reexamination of the Evidence." Journal of Political Economy 93:561-573.

Card, David, and Thomas Lemieux. 2001. "Can Falling Supply Explain the Rising Return to College for Younger Men? A Cohort-Based Analysis." Quarterly Journal of Economics 116:705-746.

Connelly, Rachel, and Peter Gottschalk. 1995. "The Effect of Cohort Composition on Human Capital Accumulation across Generations." Journal of Labor Economics 13:155-176.

Easterlin, Richard A. 1961. "The American Baby Boom in Historical Perspective." American Economic Review 51:869-911. 
Falaris, Evangelos M., and H. Elizabeth Peters. 1992. "Schooling Choices and Demographic Cycles." Journal of Human Resources 27:551-574.

Freeman, Richard B. 1979. "The Effect of Demographic Factors on AgeEarnings Profiles." Journal of Human Resources 14:289-318.

Goldin, Claudia. 1992. Understanding the Gender Gap: An Economic History of American Women. New York: Oxford University Press.

Herd, Pamela. 2005. "Ensuring a Minimum: Social Security Reform and Women." The Gerontologist 45:12-25.

Katz, Lawrence F., and Kevin Murphy. 1992. "Changes in Relative Wages, 1963-1987: Supply and Demand Factors." Quarterly Journal of Economics 107:35-78.

Munnell, Alicia H., and Annika Sundén. 2004. Coming Up Short: The Challenge of 401 (k) Plans. Washington, DC: Brookings Institution Press.

Murphy, Kevin, Mark Plant, and Finis Welch. 1988. "Cohort Size and Earnings in the USA." Economics of Changing Age Distributions in Developed Countries, pp. 39-58.

Murphy, Kevin, and Finis Welch. 1992. "The Structure of Wages." Quarterly Journal of Economics 1:285-325.

Welch, Finis. 1979. "Effects of Cohort Size on Earnings: The Baby Boom Babies' Financial Bust." Journal of Political Economy 87:S65-S97.

\section{A Imputing labor market experience}

Past labor market experience is not reported in the CPS, and so we imputed average years of full-time labor market experience based on synthetic 
labor participation histories that we constructed by gender and educational attainment for each single year birth cohort.

The synthetic labor participation histories are based on decennial population census micro-data (IPUMS) samples for the years 1940, 1950, and 1960, along with March CPS data for 1964-2004. Census data prior to 1940 do not include information on educational attainment comparable to that which we use in this study, and so could not be used. For the years available (1940, 1950, 1960, and 1964-2004) we calculate the mean full-time employment ratio for each year/gender/age/education group. That is, for each cell in the year/gender/age/education matrix we find the percent of people working full-time (which we define as working 45 or more weeks per year and 35 or more hours of work in the previous week; in 1960, we treat 40 or more weeks per year as full time due to data limitations). Because we lack data for years prior to 1940, we assume that full-time participation rates were constant from 1900 to 1940. We use linear interpolation to impute mean full-time participation rates for years between the decennial censuses and between 1960 and 1964. The final step in the imputation is to create a running sum of the full-time participation rates for each birth-year cohort (by gender and educational attainment). This yields a measure of mean years of full-time labor market experience for each birth-year cohort/age/gender/educational attainment combination. 
Figure 1: Changes in the Distribution of the Working Age Population over Time
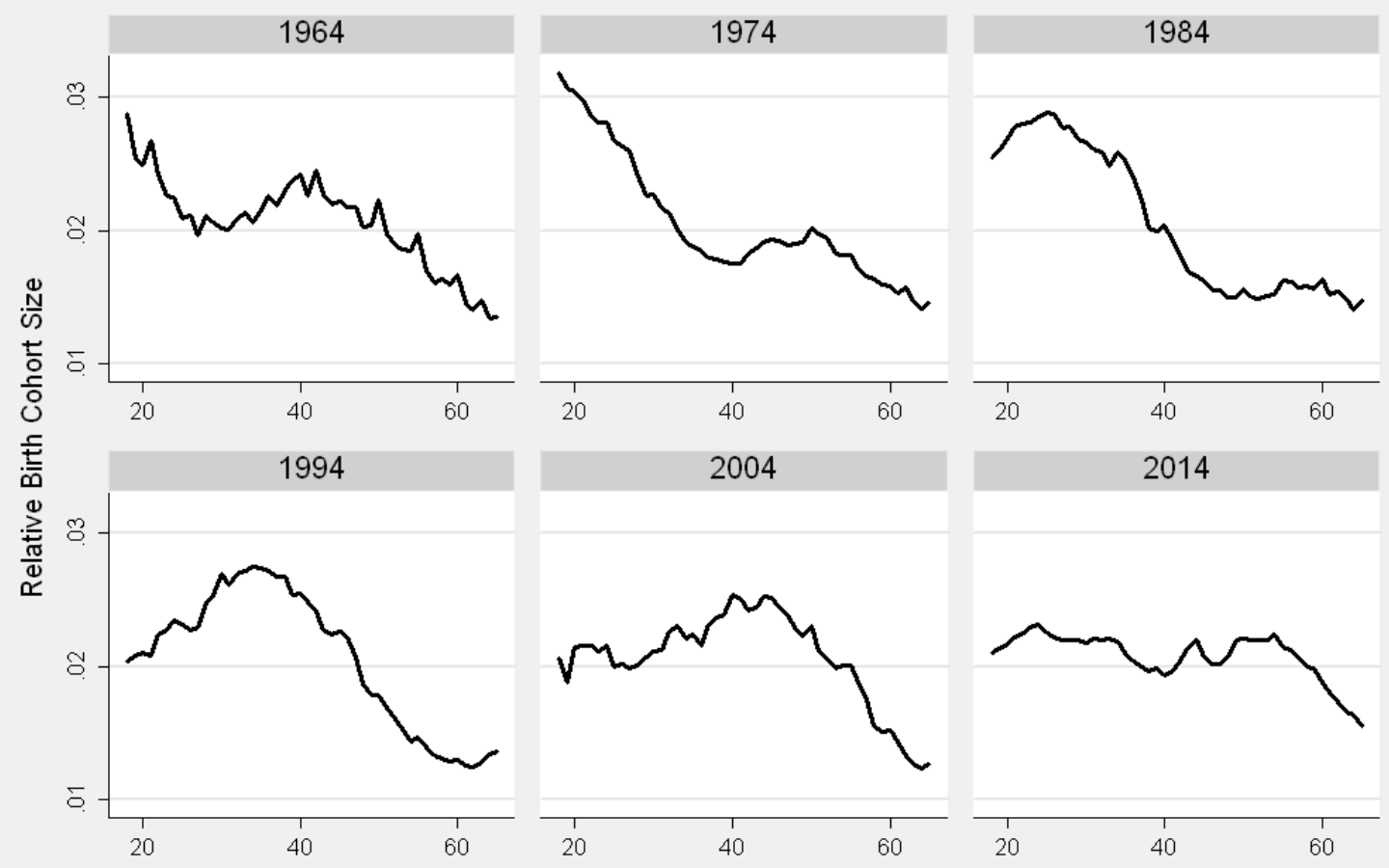

Source: authors' calculations
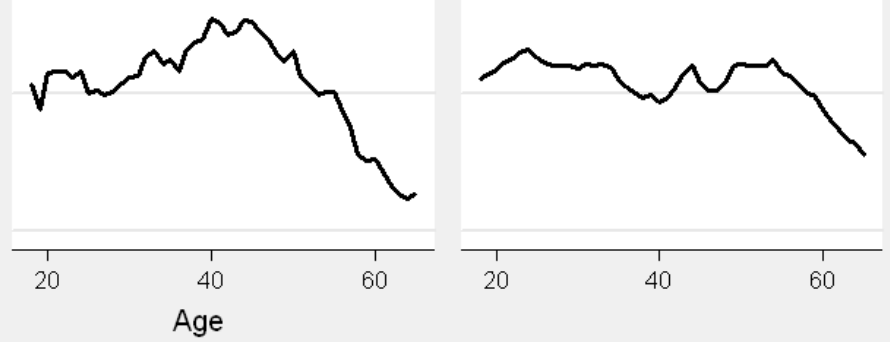
Figure 2: The Evolution of Labor Market Experience for Women

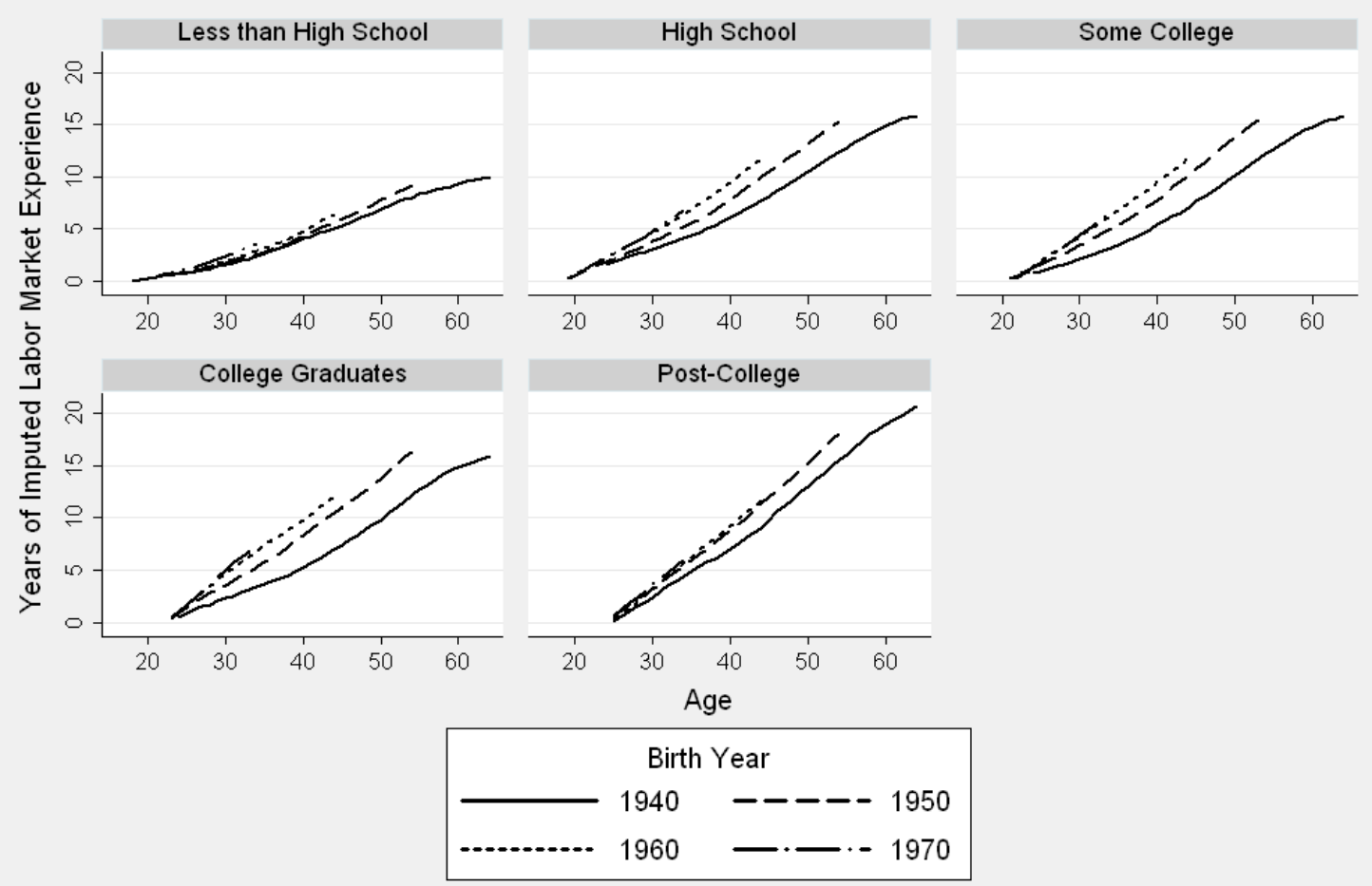

Source: Authors' Calculations 
Figure 3: The Evolution of Labor Market Experience for Men

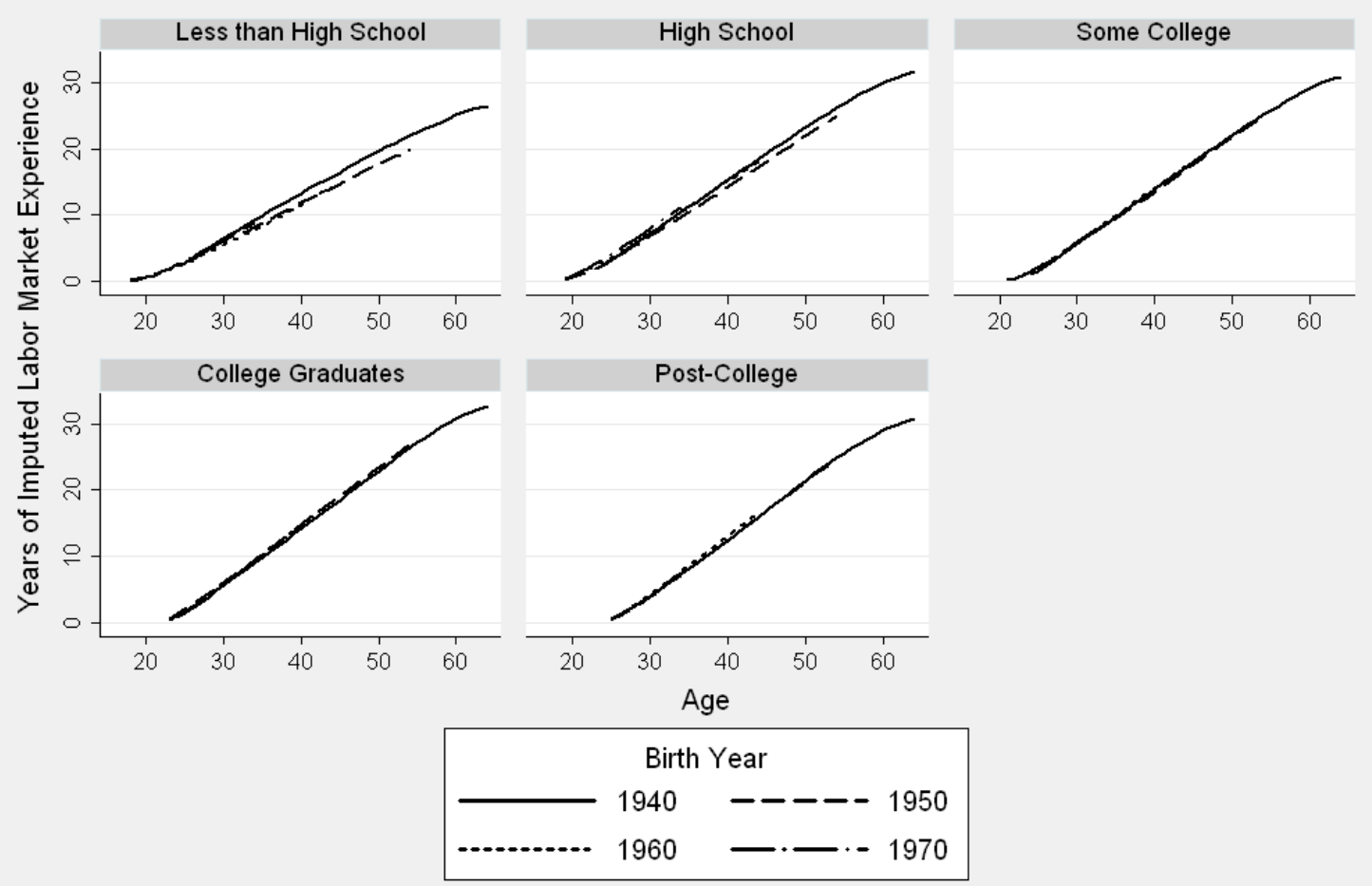

Source: Authors' Calculations 
Figure 4: Changes in the Distribution of Labor Market Experience for Men

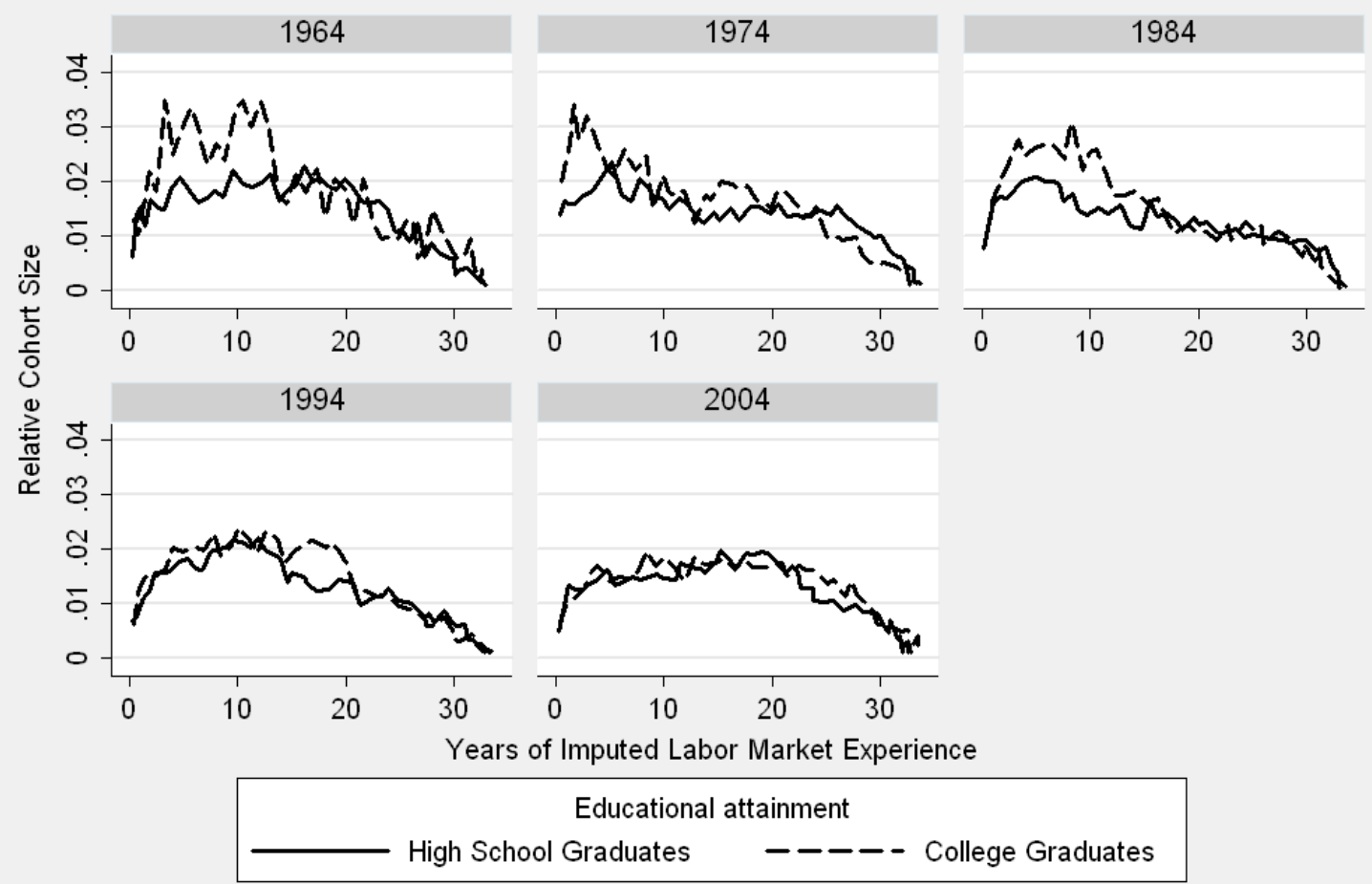

Source: authors' calculations 
Figure 5: Changes in the Distribution of Labor Market Experience for Women

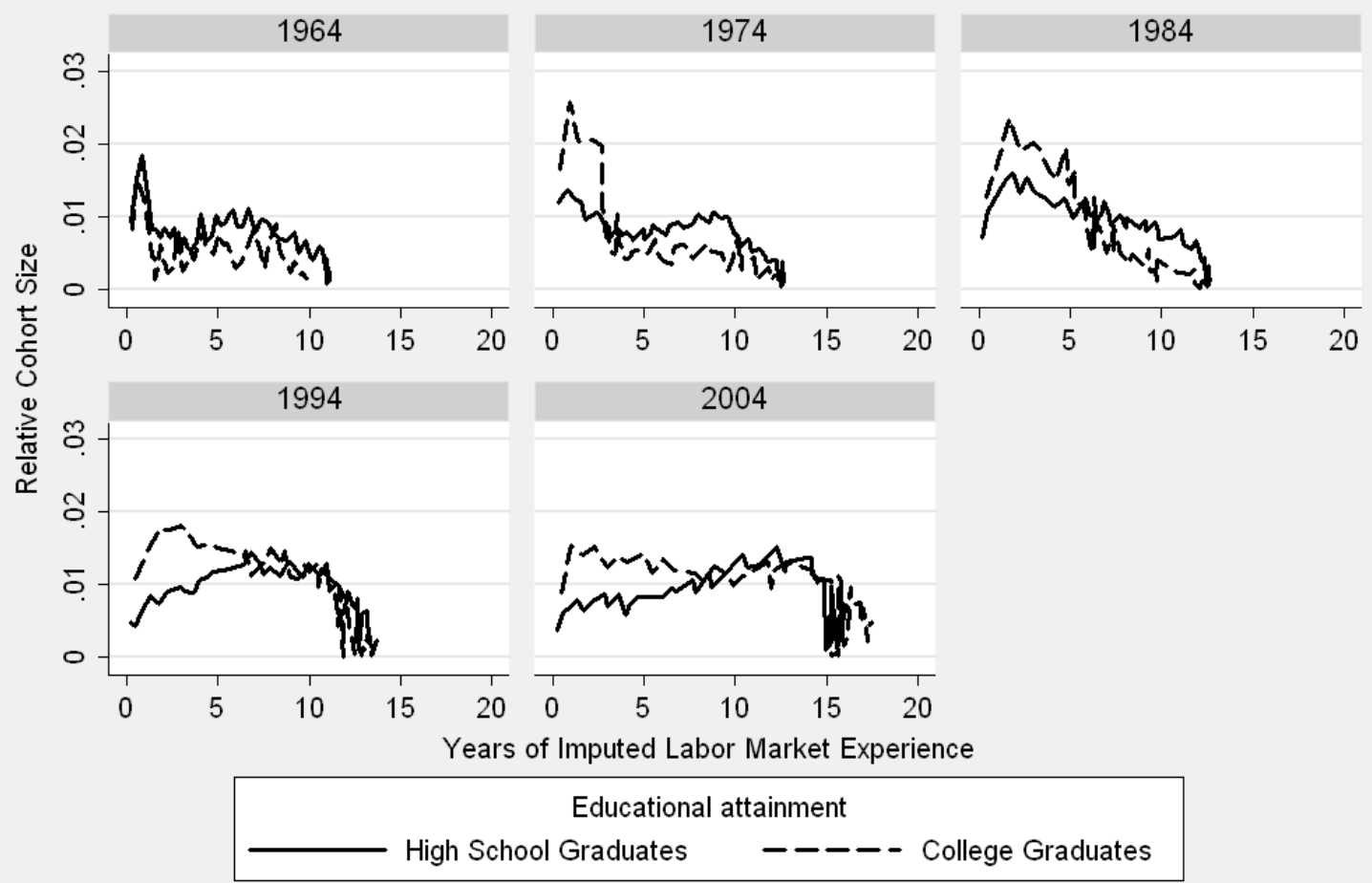

Source: authors' calculations 
Figure 6: Changes Over Time in the Experience Premium

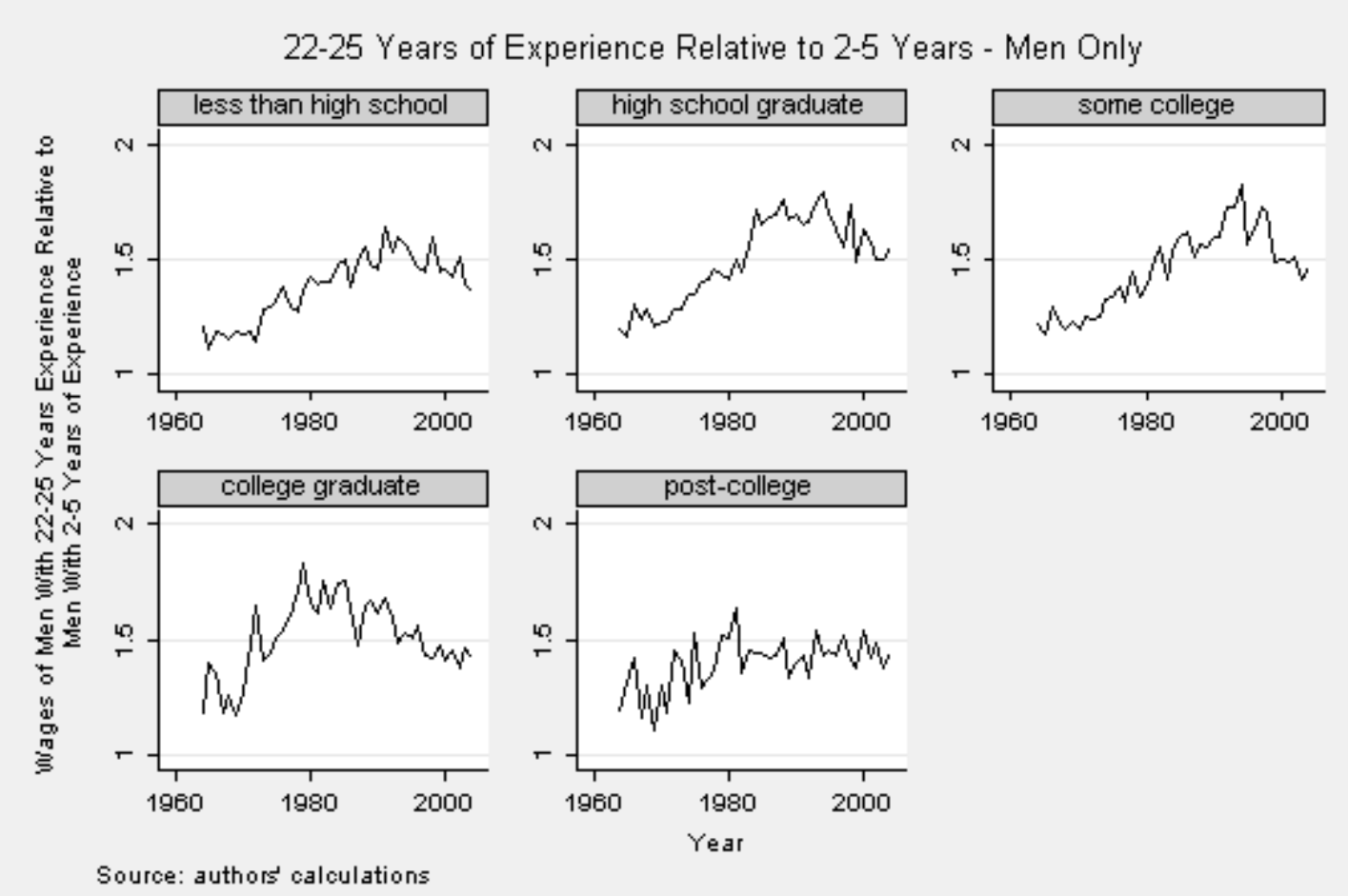

10-13 Years of Experience Relative to 2-5 Years

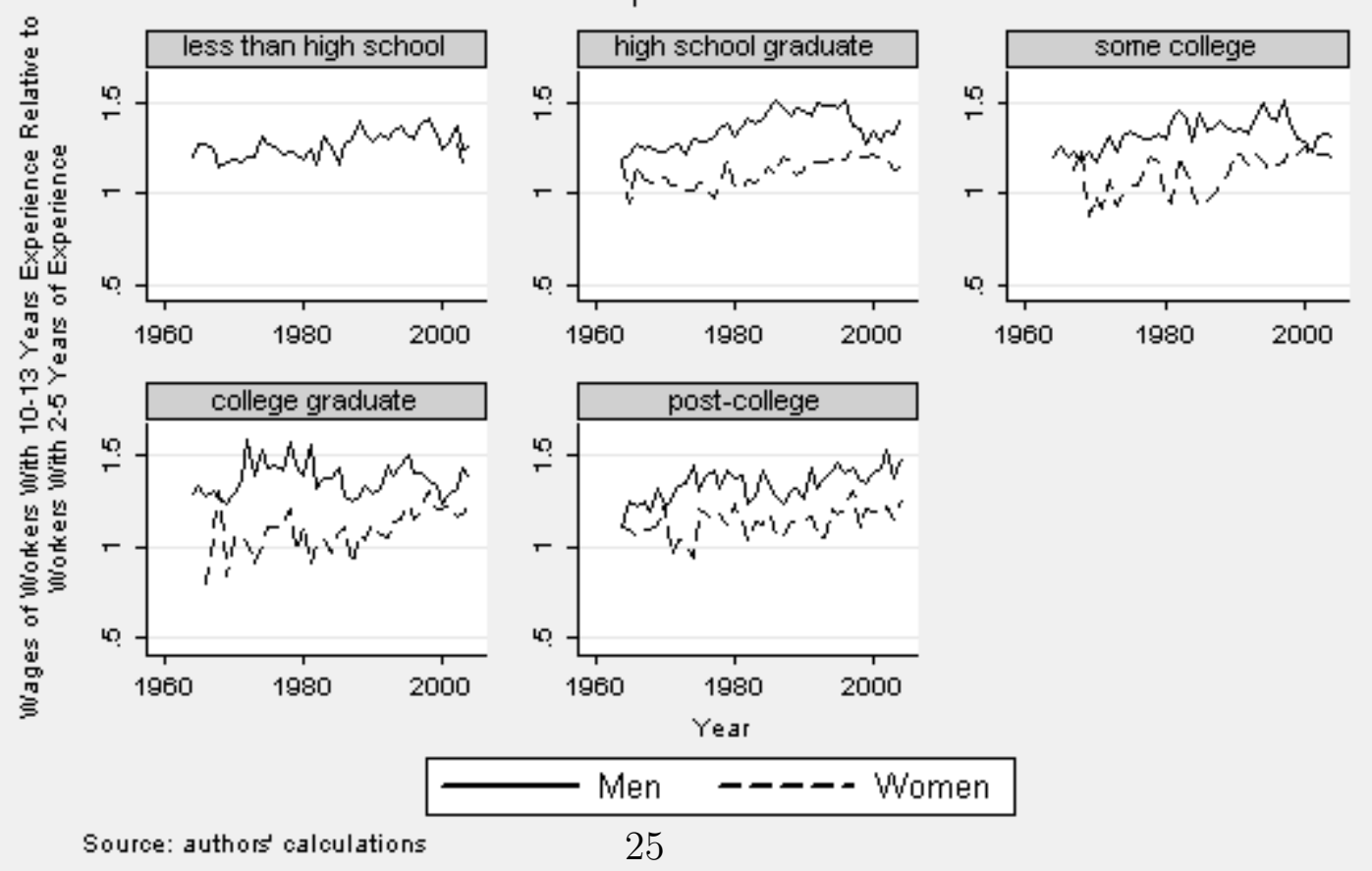


Figure 7: The Evolution of Relative Cohort Size

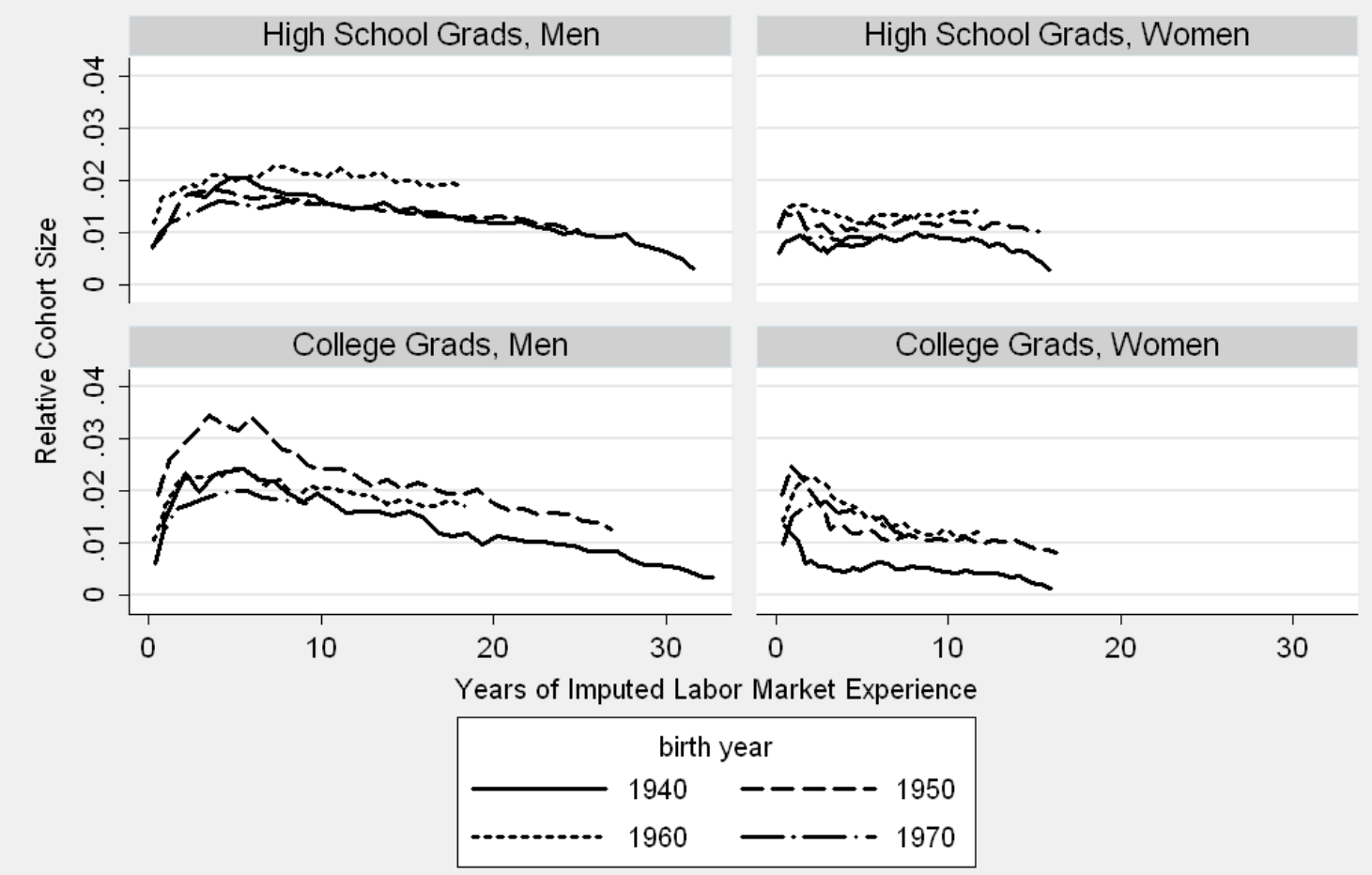

source: authors' calculations 


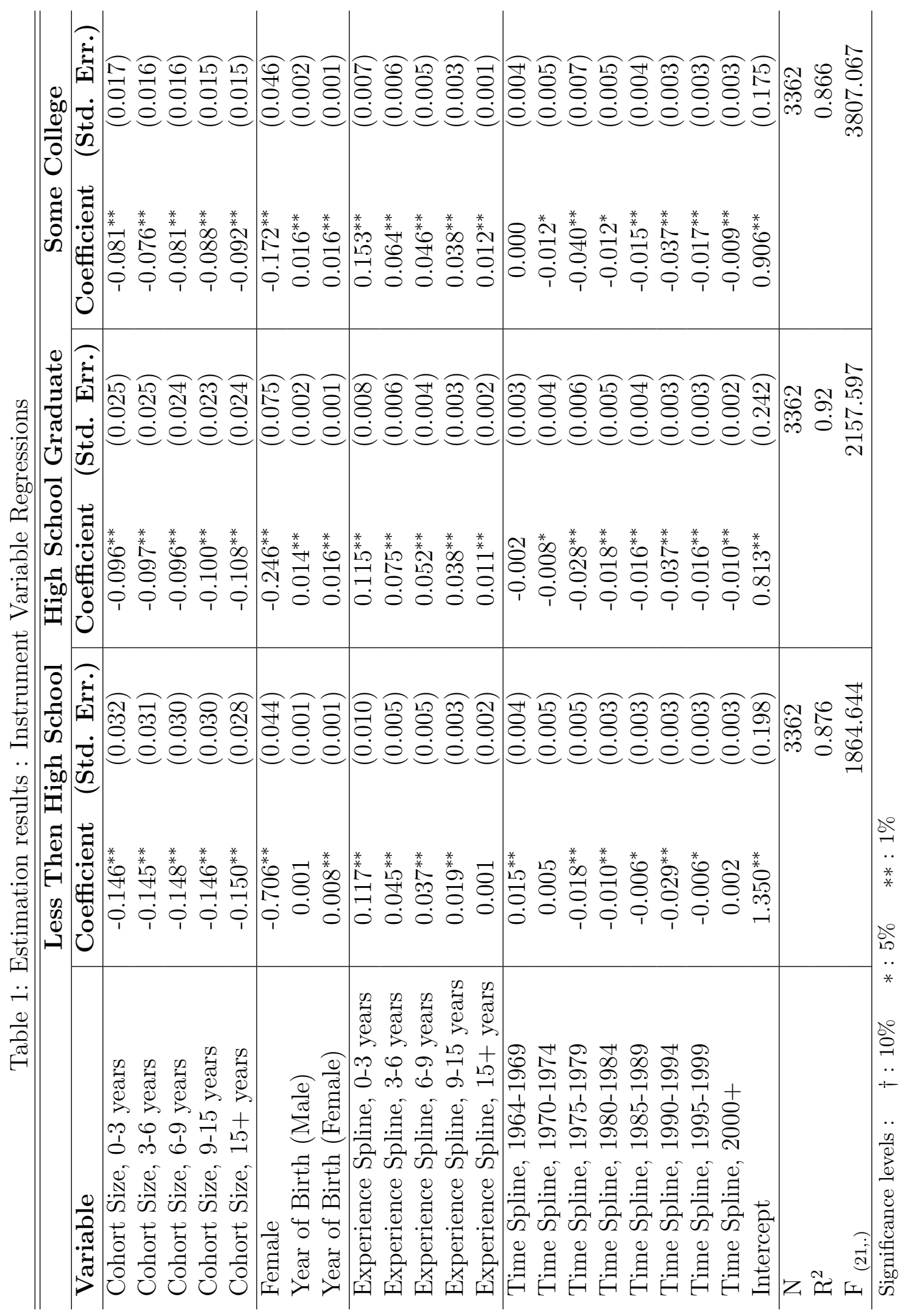




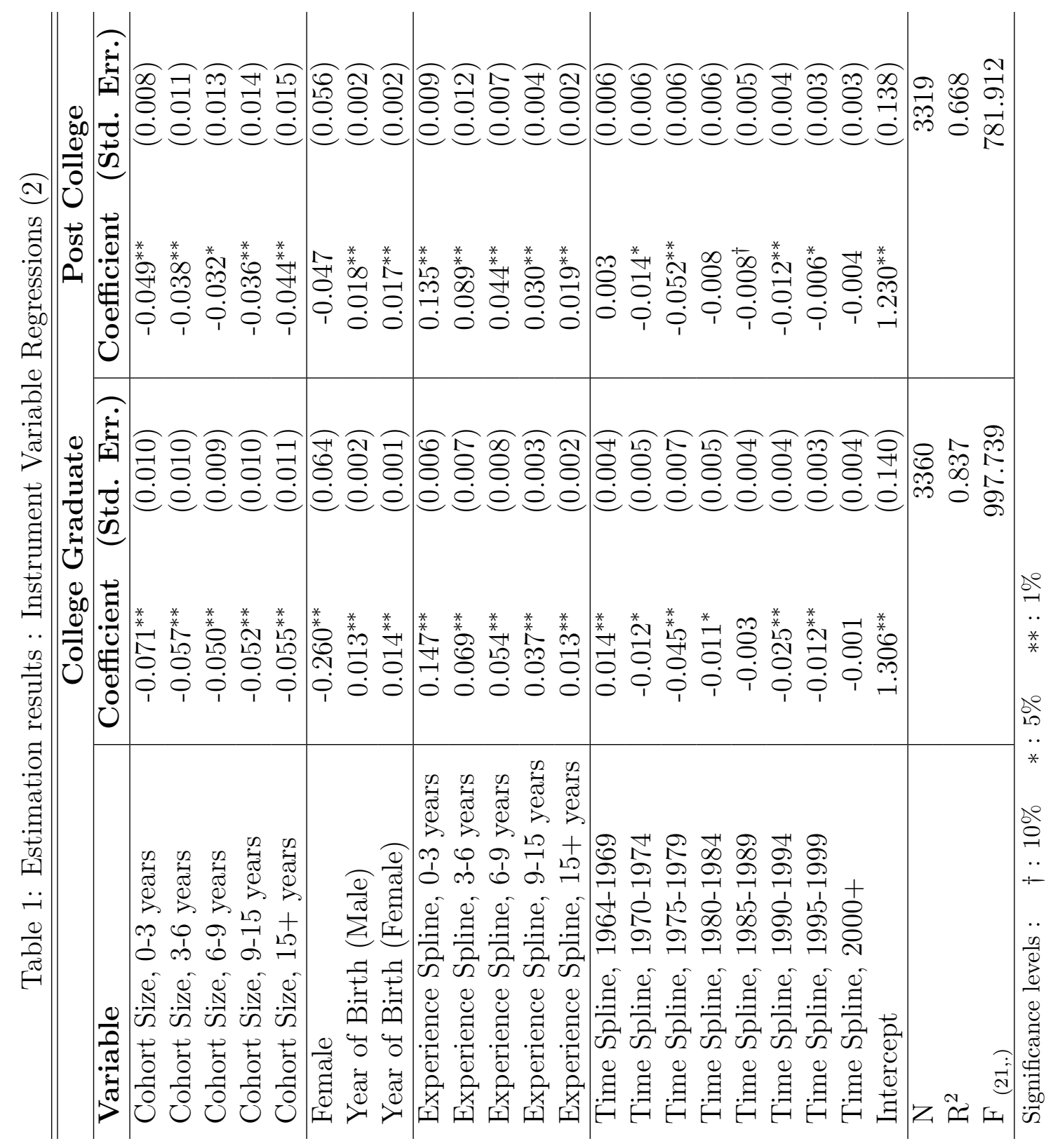




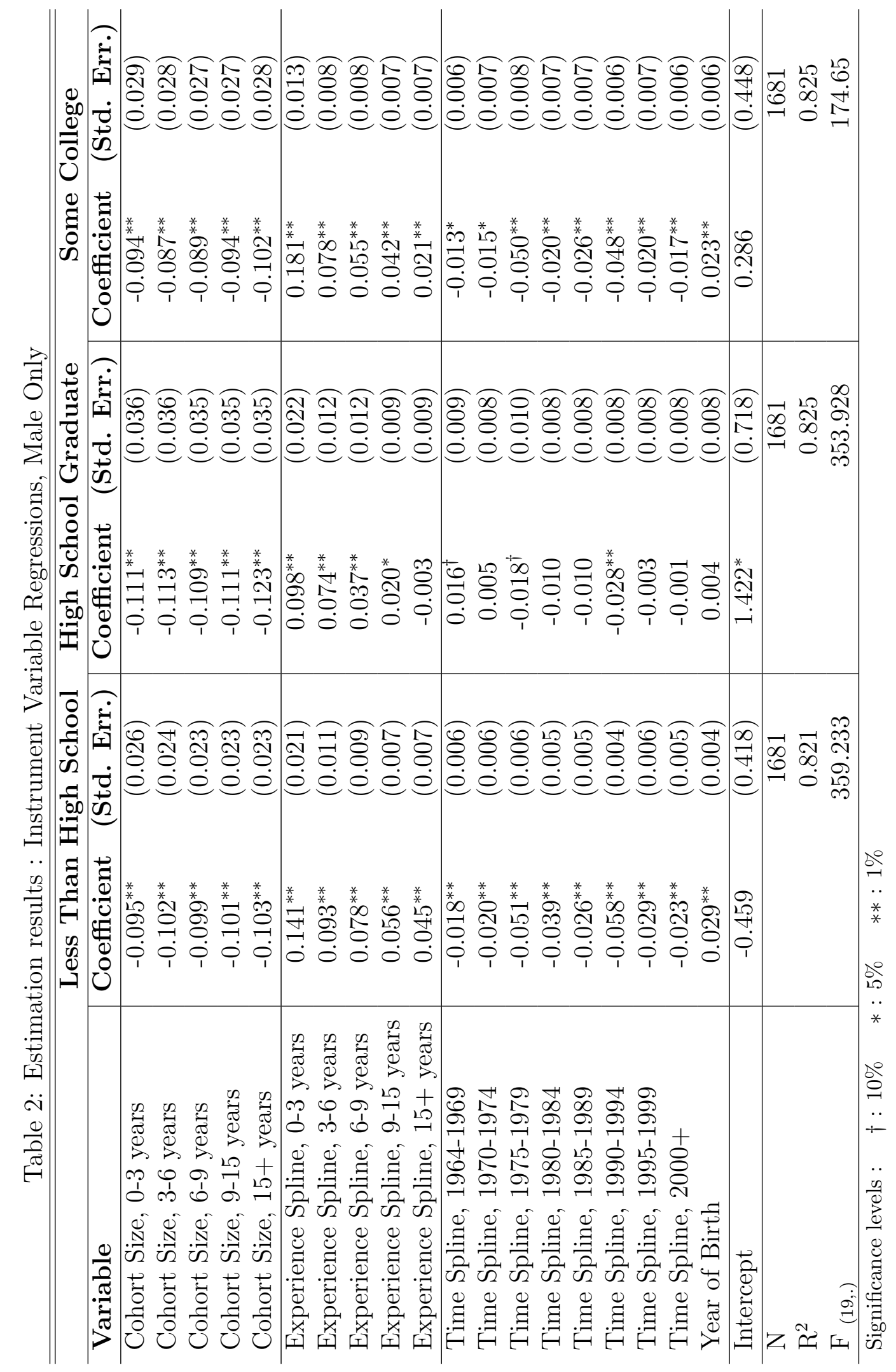




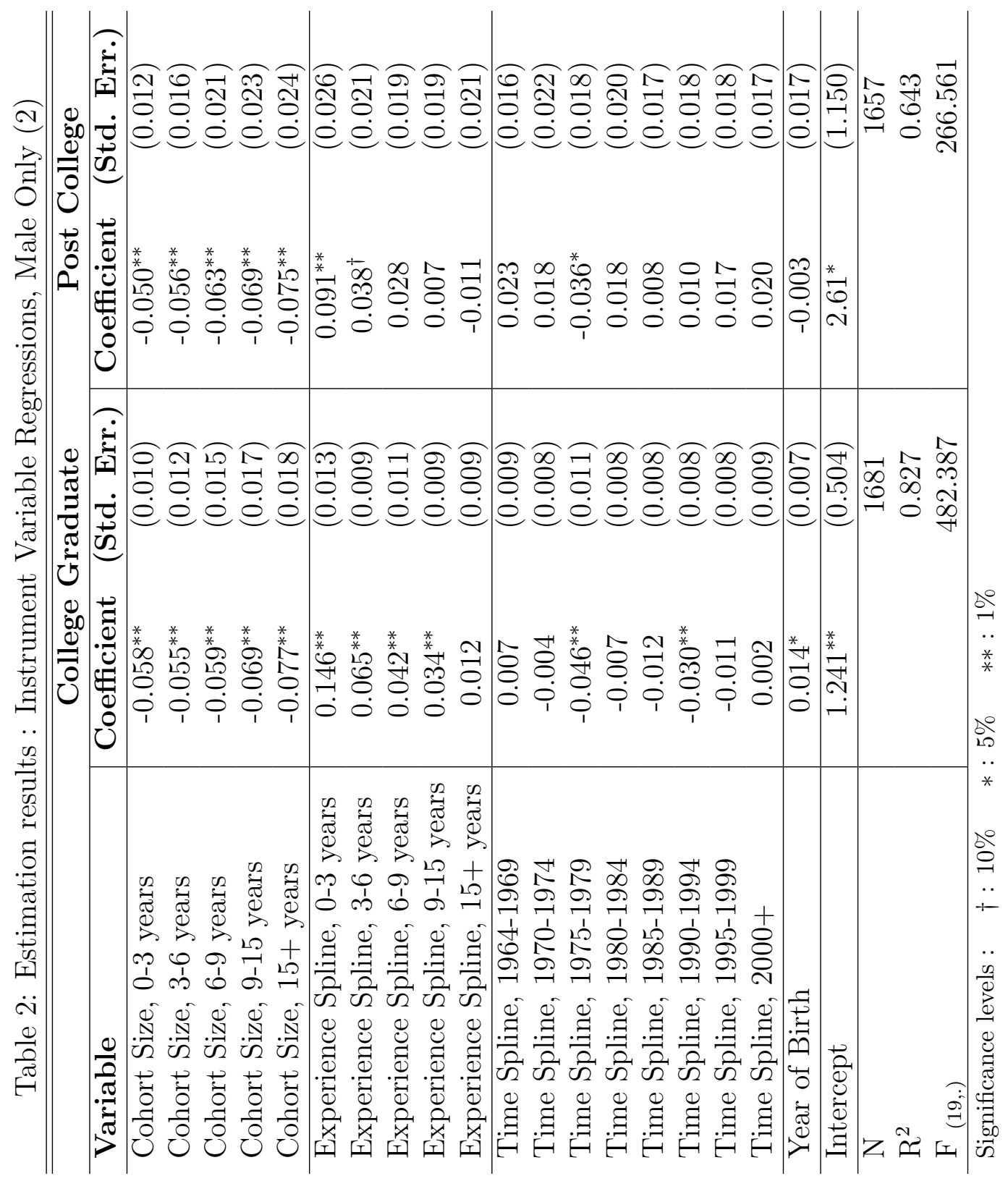




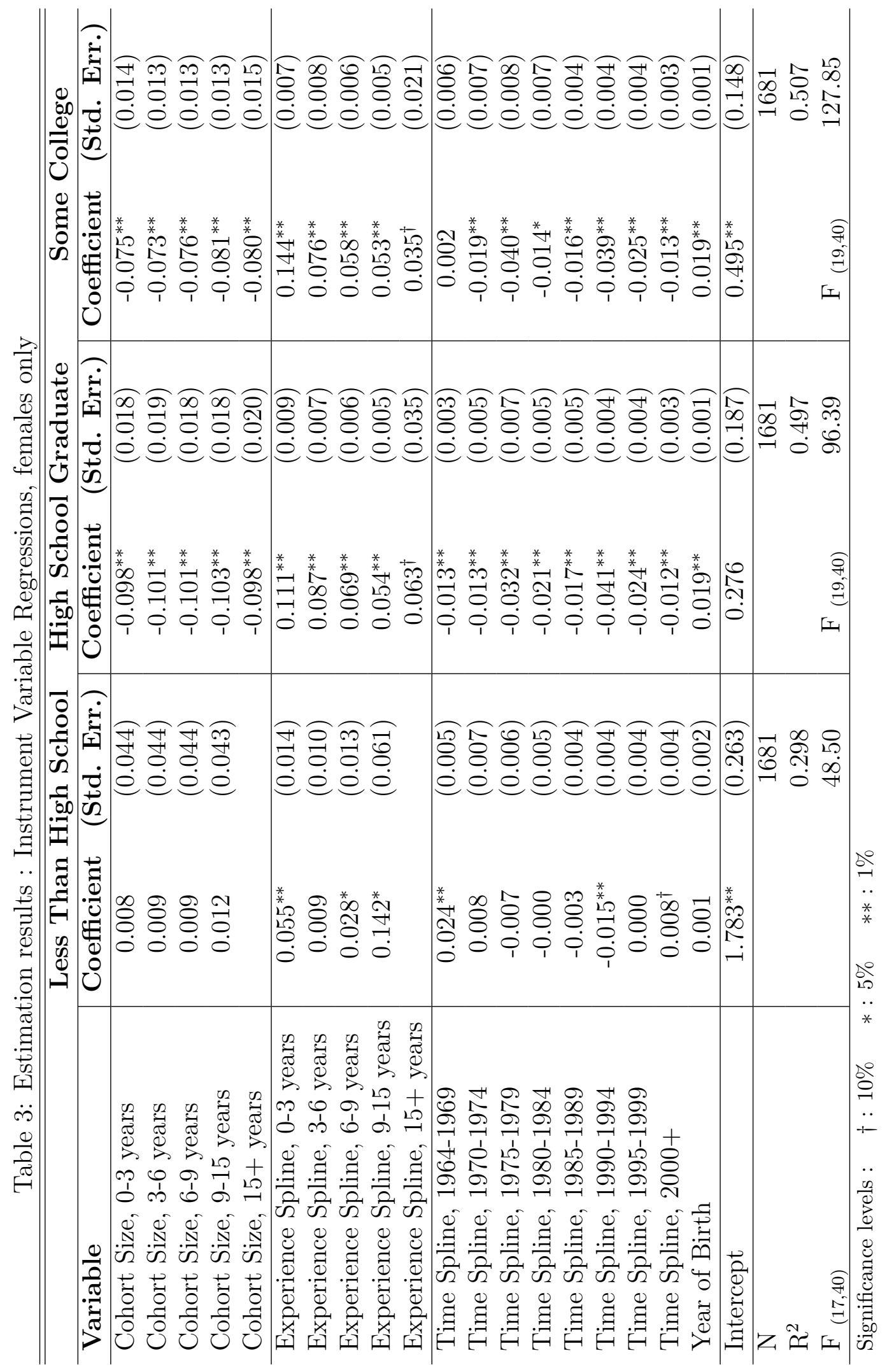




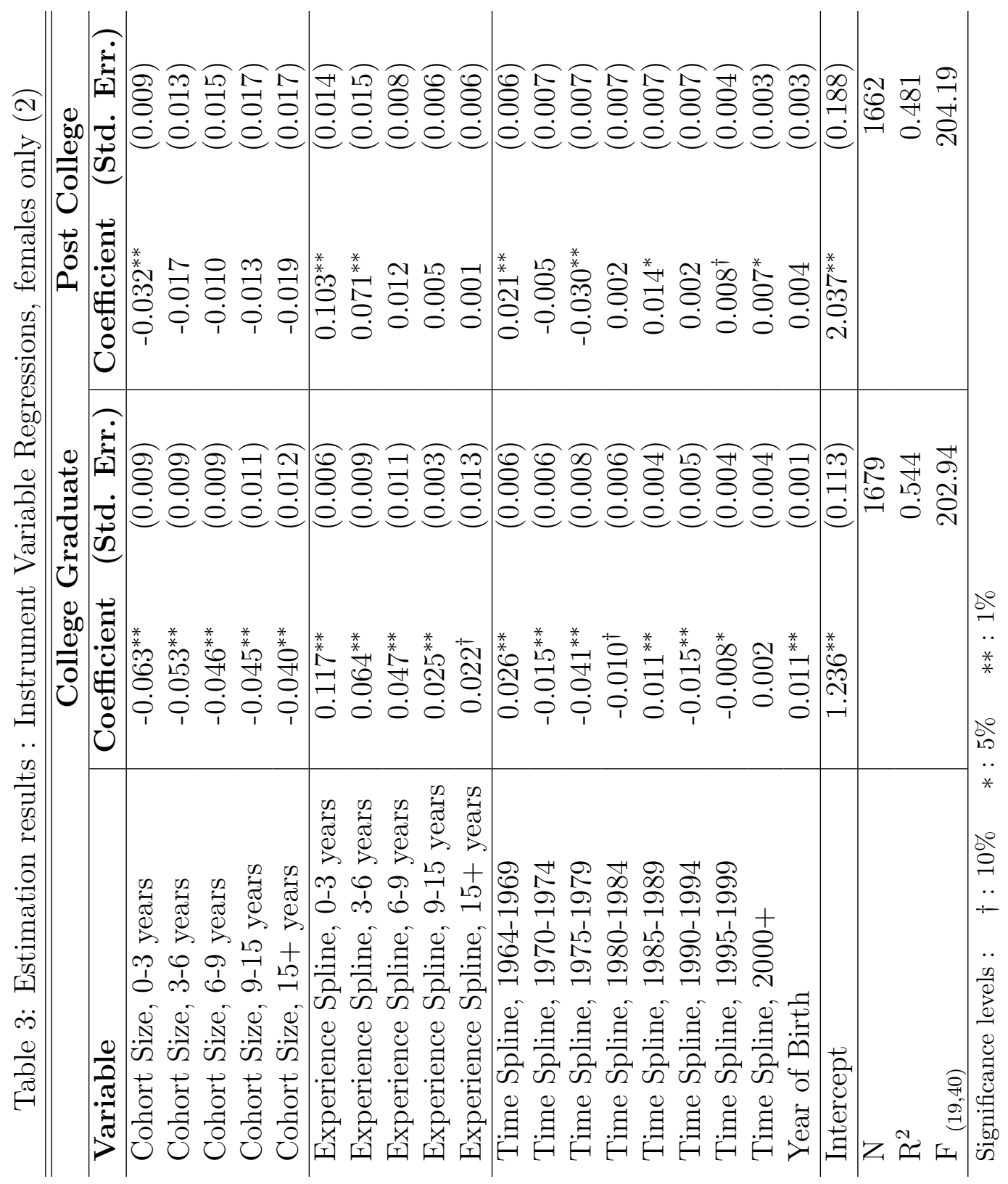




\section{RECENT WORKING PAPERS FROM THE}

\section{CENTER FOR RETIREMENT RESEARCH AT BOSTON COLLEGE}

Work at Older Ages: Is Raising the Early Retirement Age an Option for Social Security Reform?

John A. Turner, August 2007

The Labor Supply of Older Americans

Alicia H. Munnell and Steven A. Sass, May 2007

Why Do Japanese Workers Remain in the Labor Force So Long?

John B. Williamson and Masa Higo, May 2007

Literacy, Trust and the 401(k) Savings Behavior

Julie R. Agnew, Lisa Szykman, Stephen P. Utkus, and Jean A. Young, May 2007

The Recent Evolution of Pension Funds in the Netherlands: the Trend to Hybrid DB-DC Plans and Beyond

Eduard H.M. Ponds and Bart van Riel, May 2007

Demographic Influences on Saving-Investment Balances in Developing and Developed Economies

Ralph C. Bryant, May 2007

Social Security Spouse and Survivor Benefits for the Modern Family

Melissa M. Favreault and C. Eugene Steuerle, February 2007

How Economic Security Changes During Retirement

Barbara Butrica, February 2007

International Investment for Retirement Savers: Historical Evidence on Risk and Returns

Gary Burtless, February 2007

Job Changes at Older Ages: Effects on Wages, Benefits, and other Job Attributes Richard W. Johnson and Janette Kawachi, February 2007

Cross-National Comparison of Income and Wealth Status in Retirement: First Results from the Luxembourg Wealth Study (LWS)

Eva Sierminska, Andrea Brandolini and Timothy M. Smeeding, February 2007 